УДК 657

DOI: https://doi.org/10.26642/jen-2020-4(94)-69-73

Ж.В. Прокопенко, к.е.н.

І.М. Мельник, здобувач

Державний університет «Житомирська політехніка»

\title{
Механізм формування аналітичного забезпечення управління діяльністю лісогосподарських підприємств
}

У сучасних умовах розвитку лісового господарства є потреба в постійній оціниі ефективності системи управління. Це обумовлено тим, щуо лісогосподарські підприємства є суб'єктами господарювання, діяльність яких направлена на використання, зберігання та примноження стратегічного природного ресурсу Украӥни. Мета статті полягає в дослідженні механізму формування аналітичного забезпечення управління діяльністю лісогосподарських підприємств. У процесі дослідження було встановлено, що економічний аналіз є особливою функціональною економічною наукою, яка проявляе себе як сукупність нових знань $і$ на рівні наукових досліджень, $i$ на рівні практики застосування його інструментарію. Встановлено, щуо отримані в результаті аналітичного інструментарію інформаційні ресурси перетворюються в систему спеціальних знань, щзо визначає тенденщї розвитку економічних систем різних рівнів. Визначено, що економічний аналіз як науку та практичну діяльність можна розглядати з декількох аспектів: економічний аналіз як система генерування нових спеціальних знань, щзо в результаті визначають тенденції розвитку економічної науки; економічний аналіз як система генерування основного ресурсу постіндустріальної економіки інформачї̈; економічний аналіз як засіб прийняття ефективних управлінських рішень в умовах динамічного розвитку зовнішнього середовища та жорстокої конкуренції. Економічний аналіз дозволяє ідентифікувати напрями розвитку підприємства для забезпечення його стійкого розвитку в умовах невизначеності.

Ключові слова: аналіз; аналітичне забезпечення; лісогосподарські підприємства; лісогосподарська діяльність; аналітичний інструментарій.

Актуальність теми. Аналітичне забезпечення управління діяльністю лісогосподарських підприємств має розвиватися в контексті розвитку передових механізмів та методології економічного аналізу як прикладної економічної науки. Лисичко А.М. розглядаючи проблеми розвитку економічного аналізу лісогосподарської діяльності, зазначає: «Розвиток будь-якої функціональної науки є динамічним та знаходиться в постійній трансформації, що обумовлено змінами у функціонуванні об'єкта дослідження його внутрішніми та зовнішніми детермінантами. Не $є$ виключенням економічний аналіз як функціональна економічна наука, об'єктно-предметна сфера якого лежить у площині діяльності суб'єктів господарювання різних галузей національного господарства. В цьому контексті лісогосподарська діяльність також $є$ об'єктом економічного аналізу як науки та як практичної діяльності, специфікою якої є перетин економічних, соціальних та екологічних інтересів стейкхолдерів. Якщо економічний аналіз як наука визначає розширення теоретико-методологічних положень економічного аналізу в контексті пошуку причинно-наслідкових зв'язків стану та розвитку лісогосподарської діяльності, зважаючи на економічні, екологічні та соціальні властивості, то економічний аналіз як практична діяльність визначається сукупністю методик, які дозволяють виявити причини, оцінити наслідки та сформувати рекомендації 3 розвитку лісогосподарської діяльності для користувачів різних рівнів» [4, с. 21].

Фактично економічний аналіз є єдиною інформаційною підсистемою управління діяльністю лісогосподарських підприємств, яка дозволяє повною мірою сформувати інформацію про ефективність господарської діяльності як з позиції економічної ефективності, так і екологічної. Складність системи економічного аналізу діяльності лісогосподарських підприємств полягає в тому, що зацікавлені сторони вимагають рівносторонньої інформації від економічної результативності діяльності лісогосподарського підприємства до ефективності використання природних ресурсів та їх збереження. Усе зазначене впливає на розвиток системи економічного аналізу й відповідно формування аналітичного забезпечення управління діяльністю лісогосподарським підприємством.

Аналіз останніх досліджень та публікацій. Питання розвитку економічного аналізу в системі управління діяльністю лісогосподарських підприємств порушувалися в працях таких вчених, як: В.В. Свдокимов, Д.О. Грицишен, О.М. Дзюбенко, А.М. Лисичко, Т.І. Вовчук, О.А. Зоріна, Н.А. Случак, Л.Р. Воляк, Н.С. Дружинська, Х.Р. Хомик, О.В. Шавурська, Т.М. Ковальчук, В.К. Савчук, І.В. Саух, О.В. Олійник та інші. Роблячи акцент на вагомий внесок вчених у розвиток системи економічного аналізу діяльності лісогосподарських підприємств, сьогодні залишаються невирішеними питання, що стосуються трансформації окремих складових системи та напрямів формування аналітичного забезпечення управлінських рішень.

(C) Ж.В. Прокопенко, I.М. Мельник, 2020 
Мета статті - дослідити механізм формування аналітичного забезпечення управління діяльністю лісогосподарських підприємств.

Викладення основного матеріалу. «Розвиток будь-якої функціональної науки є динамічним та знаходиться в постійній трансформації, що обумовлено змінами у функціонуванні об'єкта дослідження його внутрішніми та зовнішніми детермінантами. Не $\epsilon$ виключенням економічний аналіз як функціональна економічна наука, об'єктно-предметна сфера якого лежить в площині діяльності суб'єктів господарювання різних галузей національного господарства. В цьому контексті лісогосподарська діяльність також $\epsilon$ об’єктом економічного аналізу як науки та як практичної діяльності, специфікою якої є перетин економічних, соціальних та екологічних інтересів стейкхолдерів. Якщо економічний аналіз як наука визначає розширення теоретико-методологічних положень економічного аналізу в контексті пошуку причинно-наслідкових зв'язків стану та розвитку лісогосподарської діяльності, зважаючи на економічні, екологічні та соціальні властивості, то економічний аналіз як практична діяльність визначається сукупністю методик, які дозволяють виявити причини, оцінити наслідки та сформувати рекомендації 3 розвитку лісогосподарської діяльності для користувачів різних рівнів» [4].

«Економічний аналіз є особливою системою генерування інформації про економічний потенціал підприємства та його важливу складову - фінансову безпеку. Сучасні теорія та методологія економічного аналізу не повною мірою дозволяють генерувати інформацію, яка потрібна користувачам для прийняття рішень. Зауважимо, що спектр інформаційних потреб та склад користувачів $є$ різноманітними, а тому система економічного аналізу має бути динамічною та мінливою до особливостей внутрішнього й зовнішнього середовищ. Те, що діюча система економічного аналізу не повною мірою відповідає сучасним вимогам, є об’єктивною ознакою, адже розвиток економічних відносин та їх властивостей значно прискорився на початку XXI ст. Мінливість як властивість економічного аналізу полягає в тому, що трансформація має відбуватися як на методологічному рівні - зміна існуючих інструментів та формування нових, так і на суб'єктному - розвиток професійних компетентностей аналітика, формування етичних положень та зміна його місця в системі управління та об'єктному - дослідження об'єкта управління 3 позиції його властивостей, їх зміни та взаємозв'язку із іншими. Виходячи із зазначеного, система економічного аналізу має багатоаспектний прояв у системі управління та займає особливе місце в інформаційному моделюванні механізмів забезпечення фінансової безпеки підприємства» [5].

Так на практиці економічний аналіз проявляється як інформаційна система, що забезпечує відповідні інформаційні запити управління господарською діяльністю підприємств усіх галузей національної економіки. Водночас отримані в результаті аналітичного інструментарію інформаційні ресурси перетворюються в систему спеціальних знань, що визначає тенденції розвитку економічних систем різних рівнів (макроекономіка, мікроекономіка, міжнародна економіка). Наприклад, отримана в результаті економічного аналізу діяльності підприємств лісового господарства інформація, в першу чергу, використовується як інформаційне підгрунтя прийняття управлінських рішень суб'єктами управління як на рівні підприємства, так і на рівні галузі - Державне агентство лісових ресурсів України; а також як основа розвитку економічної системи певного рівня, як об’єкта наукового дослідження. В цілому така інформація є основою для прийняття рішень у системі державного правління.

«Розвиток організації та методики будь-якого економічного об'єкта управління господарською діяльністю підприємств, різних за розміром, галуззю та організаційно-правовою формою, вимагає оцінки та ідентифікації його властивостей. Підприємства лісового господарства є специфічними суб'єктами господарювання, що визначаються державною формою власності та галузевою специфікою використанням природних (лісових) ресурсів. Це, в свою чергу, визначає особливості економічного аналізу як системи формування інформаційного забезпечення управління лісогосподарською діяльністю та оцінки причинно-наслідкових зв'язків основних показників. Обгрунтовано, що лісогосподарська діяльність $є$ місцем перетину економічних, соціальних та екологічних процесів й, відповідно, інтересів різних учасників господарських відносин. Виходячи з цього, ідентифіковано риси та складові державного впливу на господарську діяльність підприємств лісогосподарської галузі та представлено характеристику послуг, які надають зазначені підприємства» [4].

Варто зауважити, що результати застосування аналітичних процедур в цілому можуть бути використані в контексті окреслення тенденцій розвитку різних економічних наук (економічна теорія, економіка підприємства, регіональна економіка, національна економіка, міжнародна економіка, економіка сталого розвитку), так і інших суспільних та поведінкових наук, психологія - біхевіоризм в економічних відносинах, державне управління - розробка та впровадження державної політики (економічна, екологічна, кадрова, фінансова та інші політики держави), соціологія - взаємодія суспільства та екосистем; право - система нормативно-правового регулювання лісокористування; державна та національна безпека оцінка ризиків антропогенного впливу на рівень безпеки держави та інші.

В цілому економічний аналіз як науку та практичну діяльність можна розглядати з декількох аспектів:

- економічний аналіз як система генерування нових спеціальних знань, що в результаті визначають тенденції розвитку економічної науки. Економічний аналіз володіє таким метрологічним інструментарієм, 
що дозволяє оцінити тенденції розвитку економічних систем з погляду наукового дослідження, що в результаті призводить до генерування нових наукових знань. «Як відомо, економічний аналіз як наука репрезентує собою систему спеціальних знань, яка пов'язана: а) з дослідженням економічних процесів у їх взаємозв'язку, що складаються під дією об'єктивних економічних законів і суто суб'єктивних факторів; б) з науковим обгрунтуванням бізнес-планів та об'єктивною оцінкою їх виконання; в) з виявленням позитивних і негативних факторів та кількісним вимірюванням їх дії; г) з розкриттям тенденцій і пропорцій господарського розвитку та визначенням невикористаних внутрішньогосподарських резервів; д) 3 узагальненням передового досвіду та прийняттям оптимальних управлінських рішень. Дослідження економічних процесів розпочинається з одиничного (з окремого факту господарського) явища чи ситуації, які в сукупності є господарським процесом. Доцільно також зауважити, що, аналізуючи одиничне, враховуємо і загальне явище» [8, с. 159]. Так отримані спеціальні знання в результаті опрацювання вченими дозволяють розширити властивості об'єкта наукового дослідження. В окремих випадках аналітичні процедури можуть бути навіть методом наукового дослідження, за умови потреб в оцінці стану об’єкта або ж апробації інноваційних методів економічного аналізу. Методологія економічного аналізу постійно трансформується в контексті зміни запитів як з боку системи управління, так і з боку системи наукових знань;

- економічний аналіз як система генерування основного ресурсу постіндустріальної економіки інформації. Фактично економічний аналіз $є$ єдиною інформаційною підсистемою управління господарською діяльністю підприємств лісового господарства, що дозволяє надати не лише інформацію про властивості об'єкта управління, але й визначає причинно-наслідкові зв'язки та напрями пошуку резервів підвищення ефективності. «Економічний аналіз $\epsilon$ засобом створення основного ресурсу постіндустріальної економіки - інформації, невід'ємним елементом у діяльності підприємств, адже досліджує їх функціонування, вивчає резерви виробництва, дає оцінку стану аналізованого об'єкта, є базою для прийняття обгрунтованих управлінських рішень на основі наявної інформації, допомагає визначити напрями підвищення ефективності діяльності та дає змогу спрогнозувати розвиток у майбутньому. На початку свого розвитку та становлення економічний аналіз був пов'язаний тільки 3 обліком та статистикою, однак з поглибленням економічної роботи на підприємстві виникає необхідність виділення аналізу як окремої системи знань, що вивчає господарські процеси, їх взаємозв'язок, взаємозалежність і взаємозумовленість» [7, с. 233]. Особливо гостро питання ефективності стоїть для підприємств лісового господарства. «Система економічного аналізу господарської діяльності є особливим інструментом інформаційного забезпечення управлінських рішень. Динамічність економічного аналізу обумовлює зміни у структурі та змісті системи його об'єктів на підприємствах різних галузей національної економіки. Особливо гостро в умовах реформування лісового господарства стоїть проблема оцінки ефективності господарської діяльності лісогосподарських підприємств» [4]. Дзюбенко О.М. 3 цього приводу зазначає: «Лісове господарство є особливою галуззю національної економіки, яка поєднує в собі економічні та екологічні особливості розвитку суспільства. Від ефективності діяльності підприємств лісового господарства залежить функціонування інших галузей економіки та стан навколишнього середовища. Однією зі складових економічної оцінки ефективності діяльності підприємств лісогосподарської галузі є економічний аналіз фінансового потенціалу лісогосподарських підприємств. Для забезпечення його ефективності є потреба в оцінці галузевих особливостей та стану розвитку лісового господарства» [1]. Це пов'язано з тим, що використання природних ресурсів має приносити не лише економічні ефекти для суспільства та держава, але визначити екологічну ефективність 3 позиції збереження навколишнього середовища, зокрема флори та фауни лісів України;

- економічний аналіз як засіб прийняття ефективних управлінських рішень в умовах динамічного розвитку зовнішнього середовища та жорстокої конкуренції. «Динамічний розвиток сучасної економіки, швидкість науково-технічного прогресу, зростаюча конкуренція, дефіцит джерел фінансування, наявність кризових явищ, перенасичення неперевіреної інформації зумовлюють дослідження проблеми економічного аналізу як однієї з важливих складових економічних наук, що з'ясовує достовірність та надійність висновків, допомагає отримати якісну інформацію та зробити правильний вибір стратегії розвитку підприємства. Значення економічного аналізу в процесі управління в умовах нестабільності та відсутності прогнозованості змін вітчизняної економіки суттєво зростає, оскільки економічний аналіз $є$ дієвим засобом доцільності прийняття правильних управлінських рішень для стійкого та ефективного функціонування підприємства. Тому для науковців та практиків сьогодні важливим є дослідження видів саме сучасного економічного аналізу, які вкрай необхідні для функціонування того чи іншого підприємства, щоб не застосовувати на практиці застарілі види, що давно втратили свою актуальність» $[8$, c. 158$]$

- економічний аналіз дозволяє ідентифікувати напрями розвитку підприємства для забезпечення стійкого розвитку підприємства в умовах невизначеності. «Складні ринкові умови висувають особливі вимоги до планування стійкого розвитку підприємств, який має будуватися на гнучких принципах коригування цілей господарської діяльності залежно від умов, у яких функціонує підприємство. 
Забезпечення стійкого розвитку є складним завданням, адже підприємство не має змоги впливати на низку чинників, що визначають напрями його діяльності. Переважна більшість відхилень від нормального функціонування виникає через прорахунки минулих періодів, які з часом накопичуються та негативно впливають на поточне функціонування. Таким чином, досягнення стійкого фінансово-економічного стану та високого рівня конкурентоздатності вимагає від підприємства глибокого, науково обгрунтованого аналізу поточної та перспективної діяльності» [3, с. 30]. «У даний час в Україні велика кількість підприємств, що не зуміла пристосуватися до ринкових відносин, впали в глибоку кризу. Проблема неплатоспроможності, банкрутства боржника, неспроможного виконувати свої зобов'язання, - одна 3 найбільш актуальних проблем ринкової економіки. Це обумовлює потребу у виявленні факторів і причин фінансової неспроможності підприємств, об’єктивної ідентифікації ознак банкрутства за допомогою діагностичного аналізу, спрямованого на обгрунтування ефективних заходів щодо фінансового оздоровлення господарюючих суб'єктів» [6, с. 134]. Так питання є актуальним для підприємств лісового господарства. Вітчизняні вчені досліджували питання фінансового потенціалу лісогосподарських підприємств та запропонували різні рівні рейтингової оцінки. Застосування такої методики на підприємствах лісового господарства Житомирської області дозволило визначити, що підприємств мають рівень - умовно середній (табл. 1). Це вказує, що досліджувані вченими підприємстваа лісового господарства за окремими аналітичними показниками фінансового стану мають критичне значення, що значно підвищує рівень фінансово-економічної безпеки.

Таблиия 1

Результати рейтингової (бальної) оцінки лісогосподарських підприємств [1, с. 10]

\begin{tabular}{|c|c|}
\hline Підприсмство & Бал та рівень \\
\hline \multirow{2}{*}{ ДП «Малинське лісове господарство» } & 54 \\
\cline { 2 - 2 } ДП «Народицьке спеціалізоване лісове господарство» & Умовно-середній \\
\cline { 2 - 2 } ДП «Новоград-волинське дослідне лісове господарство» & Умовно-середній \\
\cline { 2 - 2 } ДП «Городицьке лісове господарство» & 61 \\
\hline \multirow{2}{*}{ ДП «Коростишівське лісове господарство» } & Умовно-середній \\
\cline { 2 - 2 } & Умовно-середній \\
\hline
\end{tabular}

Висновки та перспективи подальших досліджень. Визначені напрями прояву економічного аналізу $\epsilon$ підставою для перегляду організаційно-методичних положень економічного аналізу діяльності підприємств лісового господарства. Зауважимо, що особливістю діяльності підприємств лісового господарства України є їх організаційна форма - державні підприємства та підпорядкування регулятору Державне агентство лісового господарства.

Перша особливість визначає специфіку системи правління господарською діяльністю, порядок формування майна та джерел його утворення, а також специфіку формування та розподілу фінансових результатів. Підпорядкування Державному агентству лісового господарства України визначає особливості звітування лісогосподарського підприємства, а також напрями налагодження інформаційнокомунікаційних зв'язків щодо руху аналітичної інформації. Варто зазначити, що аналітична інформація про ефективність господарської діяльності підприємств лісового господарства може стати основою щодо оцінки управлінської діяльності, зокрема керівника підприємства, що призначається Державним агентством лісового господарства України. Перспективним напрямом подальших досліджень $є$ вивчення нормативно-правового регулювання.

\section{Список використаної літератури:}

1. Дзюбенко О.М. Економічний аналіз фінансового потенціалу лісогосподарських підприємств : дис. ... к.е.н. : спец. 08.00.09 / О.М. Дзюбенко. - Житомир, 2018. - 240 с.

2. Дзюбенко О.М. Розвиток лісового господарства в Україні як середовища прямої дії на фінансовий потенціал в контексті розвитку його аналітичної оцінки / O.M. Дзюбенко // Економічний простір : збірник наукових праць. - Дніпропетровськ : ПДАБА, 2017. - № 125. - С. 80-97

3. Казачков I.О. Сучасні підходи до аналізу господарської діяльності підприємства / І.О. Казачков, Т.О. Лісенко [Електронний ресурс]. - Режим доступу : http://www.zgia.zp.ua/gazeta/evzdia_4_030.pdf.

4. Лисичко А.М. Економічний аналіз лісогосподарської діяльності : дис. ... к.е.н. : спец. 08.00.09 / А.М. Лисичко. - Житомир, 2018. - 246 с. 
5. Норд Г.Л. Становлення національної школи економічного аналізу / Г.Л. Норд // Ефективна економіка. 2015. - № 10 [Електронний ресурс]. - Режим доступу : http://www.economy.nayka.com.ua/?op=1\&z=5919.

6. Петрицька O.C. Напрями розвитку економічного аналізу в сучасних умовах / O.C. Петрицька [Електронний pecypc]. - Режим доступу : http://web.znu.edu.ua/herald/issues/2012/eco-4-2012/131-136.pdf.

7. Шестерняк М.М. Економічний аналіз: перспективи розвитку / М.М. Шестерняк // Економічний і соціальний розвиток України у XXI столітті: національна візія та виклики глобалізації : збірник тез доповідей XV Ювілейної Міжнародної науково-практичної конференції молодих вчених (м. Тернопіль, ТНЕУ, 2930 березня 2018 р.). - Тернопіль : Економічна думка ТНЕУ, 2018. - С. 233-235.

8. Шестерняк М.M. Сучасний економічний аналіз та його основні види / М.M. Шестерняк [Електронний pecypc]. - Режим доступу : http://www.visnyk-econom.uzhnu.uz.ua/archive/20_3_2018ua/34.pdf.

\section{References:}

1. Dzjubenko, O.M. (2018), «Ekonomichnyj analiz finansovogo potencialu lisogospodars'kyh pidpryjemstv», Ph.D. Thesis of dissertation, Zhytomyr, $240 \mathrm{p}$.

2. Dzjubenko, O.M. (2017) «Development of forestry in Ukraine as an environment of direct action on financial potential in the context of the development of its analytical assessmen», Ekonomichnyj prostir, PDABA, Dnipropetrovsk, No. 125, pp. 80-97.

3. Kazachkov, I.O. and Lisenko, T.O., «Suchasni pidhody do analizu gospodars'koi' dijal'nosti pidpryjemstva», [Online], available at: http://www.zgia.zp.ua/gazeta/evzdia_4_030.pdf

4. Lysychko, A.M. (2018), Ekonomichnyj analiz lisogospodars'koi' dijal'nosti: dissertation, Zhytomyr, 246 p.

5. Nord, G.L. (2015), «Stanovlennja nacional'noi' shkoly ekonomichnogo analizu», Efektyvna ekonomika, No. 10, [Online], available at: http://www.economy.nayka.com.ua/?op=1\&z=5919

6. Petryc'ka, O.S. «Naprjamy rozvytku ekonomichnogo analizu v suchasnyh umovah», [Online], available at: http://web.znu.edu.ua/herald/issues/2012/eco-4-2012/131-136.pdf

7. Shesternjak, M.M. (2018), «Economic analysis: prospects for development», Ekonomichnyj i social'nyj rozvytok Ukrai'ny u XXI stolitti: nacional'na vizija ta vyklyky globalizacii', zbirnyk tez dopovidej XV Juvilejnoi' Mizhnarodnoi' naukovo-praktychnoi' konferencii' molodyh vchenyh, TNEU, Ternopil, pp. 233-235.

8. Shesternjak, M.M. (2018), «Suchasnyj ekonomichnyj analiz ta jogo osnovni vydy», [Online], available at: http://www.visnyk-econom.uzhnu.uz.ua/archive/20_3_2018ua/34.pdf

Прокопенко Жанна Володимирівна - кандидат економічних наук, доцент кафедри економічної безпеки, публічного управління та адміністрування Державного університету «Житомирська політехніка».

Наукові інтереси:

- дослідження діяльності небанківських фінансових установ;

- обліково-аналітичне забезпечення діяльності лісогосподарських підприємств.

Мельник Ірина Миколаївна - здобувач кафедри обліку i аудиту Державного університету «Житомирська політехніка».

Наукові інтереси:

- обліково-аналітичне забезпечення діяльності лісогосподарських підприємств.

Стаття надійшла до редакції 06.10.2020. 